\title{
Destination Brand and Travel Behavior: Testing the Effects of Destination Image and Destination Personality
}

\author{
Mohamed Ali Ahmed Obaid, PhD \\ Tourism Studies Department \\ Faculty of Tourism and Hotels, Fayoum University, Egypt
}

\begin{abstract}
Despite such important role of destination brand in predicting tourists' behavior, much ambiguity exists in understanding the causal relationships among the components of destination brand and their effects on tourists' behavior. This study was undertaken to examine the direct and indirect effects of destination image and destination personality on behavioral intentions. Four structural models were testes on a sample of 300 international tourists using structural equations modeling (SEM). After testing the dimensionality, validity and reliability using confirmatory factor (CFA) analysis, SEM's results revealed that while cognitive image and destination personality have direct positive effects on both purchase intentions and word-of-mouth intentions, there is no evidence supported the effects of affective image on behavior intentions. The best model that describe the relation between destination brand and travel behavior was validated when destination personality play a mediating role between destination image and behavioral intentions. Oman's destination planners and marketers should strive to create a positive experience for tourists.
\end{abstract}

Keywords: Tourism; Destination Brand; Destination Marketing; Travel Behavior; SEM

\section{INTRODUCTION}

As intense competition among destinations, the recognition of the role that branding can play in tourism is becoming increasingly apparent by both marketing practitioners and researchers. ${ }^{1}$ While the branding of goods and services is well documented in the generic marketing literature, the application of branding techniques to tourism destinations is still in its infancy. ${ }^{2}$ Tasci and Kozak ${ }^{4}$ rationalized that as destination branding is a relatively new phenomenon, as it did not begin to receive significant attention in the travel industry until the late 1990's.

Destination image, destination personality and positioning represent the major components of destination brand. ${ }^{5} 7$ Many authors found that destination image has significant influences on travel-related behaviors including destination choice and future travel intentions. ${ }^{8}{ }^{10}$ Also, many scholars asserted that destination personality play an important role in leveraging tourists' perceived destination image, influence tourists' behavioral intentions ${ }^{11}$, differentiating the destination from its rivals ${ }^{12}$. Conejo ${ }^{13}$ supported this assertion and documented that top tourism destinations are increasingly basing their brand identities on rich and distinct personalities as a result of strong competitive pressure. Successful implementations have been found in destinations of Spain ${ }^{14}$, and Britain ${ }^{15}$.

As the importance of the key variables of destination brand involved in this study - destination image and destination personality, the author tried to clarify the ambiguity exist regarding the relationship between destination image constructs and destination personality constructs, and concluded that cognitive destination image and affective destination image have significant positive relations with destination personality. ${ }^{16}$ The previous studies asserted the same where destination image constructs and destination personality are positively related. ${ }^{317}$ The empirical investigation of Hosany, Ekinci and Uysal ${ }^{3}$ suggested that destination image and personality are directly correlated and at least affective and accessibility scales of destination image are significantly related to the three destination personality scales (sincerity, excitement, and conviviality). Empirical evidence from Beijing conducted by $\mathrm{Xie}^{17}$ ensured the relationship between destination image and

${ }^{a}$ Dr. Mohammed Ali Ahmed Abdelaal Obaid received his PhD in tourism studies from Fayoum University, Egypt. From 2001 to 2011, he worked as demonstrator, assistant lecturer, and lecturer in the department of Tourism Studies, Faculty of Tourism and Hotels, Fayoum University, Egypt. Assistant professor is the current position in the department of International Business Administration, Salalah College of Applied Sciences, Ministry of Higher Education, Sultanate of Oman. 
destination personality. The empirical findings indicated that cognitive destination image dimensions are the direct antecedents of destination personalities of excitement, sophistication, and competence.

Despite many scholars acknowledged the importance of identified variables - destination image and destination personality - on forming a powerful destination brand and affecting travel behavior, much ambiguity exist as to the relations between destination personality and travel behavior. While Ekinci and Hosany ${ }^{11}$ argued that destination personality positively influences tourist choice behavior (intentions to recommend), Murphy, Moscardo and Benckendorff ${ }^{12}$ argued that destination personality failed to indicate a strong intention of tourists to visit the destination. Also, the role of destination personality when associated with destination image and behavioral intentions is controversial. Ekinci and Hosany ${ }^{11}$ claimed that there is a moderating effect of destination personality on the relationship between destination image and intentions to recommend. However, direct influence of destination image on tourists' behavioral intentions is also found in previous literature. ${ }^{18}$

In order to clear the above ambiguity, this study aimed to apply branding theories to tourism destinations, and examine the influence of destination brand on travel behavior. As positioning is a technical statement used only by the NTO and its marketing agencies, and not a statement that should ever be used in talking to consumers or motivating them, it is not involved in the domain of this study. Specifically, this study was undertaken to achieve the following specific objectives: (1) to measure how destination image and destination personality can affect behavioral intentions of tourists, and (2) to examine the mediating effect of destination personality on the relationship between destination image and behavioral intentions. Therefore, the research question can be expressed as: what is the most suitable structural model that supports the relation between destination brand and travel behavior?

\section{Destination Brand}

Ritchie and Ritchie ${ }^{19}$ introduced one of the most cited definitions for destination brand: "A name, symbol, logo, word mark or other graphic that both identifies and differentiates the place; furthermore, it conveys the promise of a memorable travel experience that is uniquely associated with the place; it also serves to consolidate and reinforce pleasurable memories of the place experience." Although this definition limits a brand as being only a symbol of the place, it clearly infers a brand to be related to differentiation. Blain, Levy, and Ritchie ${ }^{20}$ created a holistic definition describing the process of branding a destination as "the set of marketing activities that (1) support the creation of a name, symbol, logo, word mark or other graphic that readily identifies and differentiates a destination; (2) consistently convey the expectation of a memorable travel experience that is uniquely associated with the destination; (3) serve to consolidate and reinforce the emotional connection between the visitor and the destination; and (4) reduce customer search costs and perceived risk" (p.337).

World Tourism Organization and European Travel Commission ${ }^{21}$ defined destination brand as "the essence or competitive identity of a destination that makes it different from all other competitors in the eyes of its potential visitors" (p.8). Greaves and Skinner ${ }^{1}$ ensured the same by describing destination branding as the method of creating a unique identity for a destination that enables potential visitors to differentiate one destination from another. Saraniemia ${ }^{22}$ defined destination brand as "a holistic co-created identity based on a destination's core values interpreted by both supply (e.g., tourism businesses, government agencies) and demand (e.g., customers) side stakeholders" (p. 253). Recently, Nicolaisen and Blichfeldt ${ }^{7}$ concluded that destination branding is "a process by which destinations seek to express their unique identity through a positive projected image that is clear and well positioned in relation to competitors" (p.8).

Brand management scholars concluded that destination branding includes three main elements: image, identity, and positioning. ${ }^{567}$ Destination image is an individual's mental representation of knowledge, feelings, and overall perception of a particular destination. ${ }^{23}$ Cognitive and affective image are essential components of a destination image. ${ }^{24}{ }^{25}$ Cognitive destination image is defined as the belief and knowledge about a destination attributes, while affective destination image is the emotional feeling of tourists toward the destination. 2526

To create cognitive-affective images of a destination, many information sources are there under the image formation theory. These information sources are also known as stimulus factors ${ }^{8}$ or image forming vehicles ${ }^{27}$. Based on the source of destination image formation, various researchers in tourism studies classify destination image into three types: organic image, induced image, and complex image. ${ }^{23} 28$ An organic image arises from non-tourism information or unbiased sources such as geography books, television reports, or magazine articles. An induced image can arise from tourism-specific information such as a destination brochure or vacation web site, which is a product of destination marketing efforts. Complex image (sometimes called modified induced, composite image, primary or experience image) can be derived as a result of direct experience or visit of the destination. ${ }^{42}$

However, Aaker ${ }^{30}$, and Tasci and $\mathrm{Kozak}^{4}$ argued that destination image is an essential part of forming a powerful destination brand. This view is shared by Baloglu and Mangaloglu ${ }^{31}$ who believed that destinations mainly compete based 
on their perceived image relative to competitors in the marketplace. Destination image has significant impacts on both supply-side (destination) as well as demand-side (consumers) aspects of marketing. ${ }^{32}$ The image of a destination is an important factor in determining its popularity with visitors ${ }^{33}$ and is therefore crucial to its marketing success ${ }^{34}$.

Rather than tangible appeal of destination image, there is an increased focus among scholars ${ }^{11}{ }^{12}$ and practitioners ${ }^{13}$ on destination differentiation through intangible and emotional appeal of the destination personality or identity. Pike ${ }^{29}$ stated that destination identity and destination personality have been interchangeably used to refer to the core values and traits that best represent the destination. Adapting Aaker's research ${ }^{30}$. Hosany et al. ${ }^{3}$ defined destination personality as "the set of human characteristics associated to a tourism destination" (p. 639). Recently, UNWTO and ETC ${ }^{21}$ defined destination personality as "a succinct summation of the destination's defining characteristics that reflect how the destination would like to be seen by its key audiences" (p.45). Accordingly, sources to build up a destination personality are mainly: awareness, performance, positioning, imagery/personality, judgment, feelings, and resonance. ${ }^{35}$

Further, as suggested by Pritchard and Piggott ${ }^{5}$, identifying the personality of a destination helps in establishing a relationship between the brand and the customer. Konecnik and Go ${ }^{36}$ argued that destination personality is a unique set of associations that marketers seek to create and maintain, and a representation of the image that the destination should project to targeted visitors. Moreover, Mai suggested that destination identity is more important than image from a strategic point of view, as destination identity is the core of the brand. ${ }^{37}$

The positioning of a destination brand is the last 'step' towards the completion of destination branding. ${ }^{38}$ Positioning means "a summary of the destination's strongest competitive features comprises the positioning statement" (p.45). ${ }^{21}$ A competitive position for a destination brand in the marketplace can be developed by creating and transmitting a clear and favorable image to (potential) tourists. ${ }^{20}{ }^{37}$ Further, positioning analysis requires an understanding of how a destination is perceived to perform on attributes deemed important to the target, relative to the competition. ${ }^{39}$

\section{Destination Image, Destination Personality and Behavioral Intentions}

Behavioral intentions represents the degree of conscious effort that a person exert in order to perform a behavior ${ }^{40}$ and could be termed as an individual's likely or planned future behavior. Based on deep analysis of previous studies, behavioral intentions were examined from different perspectives, such as intention to (re)visit ${ }^{41}$, willingness to recommend to others or word-of mouth intentions ${ }^{17}{ }^{42}$, and willingness to pay more or repeat purchase intention ${ }^{43}$.

To understand why tourists have behavioral intentions, scholars focus on identifying the antecedents of behavioral intentions including destination image ${ }^{84}$, destination personality ${ }^{3}{ }^{17}$, and others such as satisfaction ${ }^{45}{ }^{46}$, quality related constructs $^{4748}$, perceived value ${ }^{41}{ }^{48}$, and past vacation experience ${ }^{49}$. As mentioned in the introductory section, the study' variables, destination image and destination personality, represent the major components of destination brand that were widely acknowledged to have strongly impacts on tourists' behavioral intentions. Most scholars agreed that destination image plays a crucial role in forming visitation intention or taking destination choice decisions. ${ }^{50}$

Previous research findings indicated that destination image had both direct and indirect effect on behavioral intentions. Baloglu and McCleary ${ }^{8}$ found that three cognitive destination image factors (quality of experience, attractions, and value/entertainment) were positively associated with word-of-mouth (i.e. willingness to recommend to others). O'Leary and Deegan $^{51}$ indicated that perceived images are the basis of the evaluation or selection process and thus provide the link between motivations and destination selection.

In 2008, the results of Gras's study ensured the direct positive relationship between destination image and intention to visit Spain destination. ${ }^{52}$ Also, Alcaniz, Sanchez and Blas ${ }^{44}$ found a direct effect of cognitive destination image on tourism behavioral intentions. More specifically, functional image was only related to revisit intention and psychological image was only related to intention to recommend, and mixed image was associated with neither of the two behavioral intentions. To examine the influences of perceived destination image on destination choice intention of university student travelers to Mauritius, Phau, Shanka and Dhayan ${ }^{10}$ used multiple regression and found that two factors of perceived destination image (namely "relaxation and escape" and "attractiveness") have direct positive significant influences on destination choice intention.

Bigne, Sanchez and Sanchez ${ }^{53}$ investigated interrelationships among destination image, perceived quality, satisfaction, intention to return, and willingness to recommend to others in the context of resort visitors. They found that destination image had a direct effect on intention to return and willingness to recommend to others. Meanwhile, destination image was also found to have an indirect effect on intention to return and willingness to recommend to others through quality and satisfaction. Chen and Tsai ${ }^{48}$ supported Bigne et al.'s findings by indicating that destination image had a direct effect on trip 
quality and behavioral intentions. In addition, destination image had an indirect effect on behavioral intentions through trip quality, perceived value, and satisfaction.

Applying a theory of market heterogeneity in their study, Castro, Armario and Ruiz ${ }^{45}$ found that there was strong an indirect relationship between a destination image and intention to visit, in which the relationship was moderated by service quality and tourist satisfaction. Chi and $\mathrm{Qu}{ }^{54}$ tested a theoretical model that examined whether or not destination image had a direct or indirect effect on behavioral loyalty using a sample of a famous spring tourists. The findings indicated that destination image was indirectly related to behavioral loyalty through attribute satisfaction and overall satisfaction. Lee ${ }^{46}$ also found the mediating effect of satisfaction between destination image and future tourism behavior, supporting the indirect effect of destination image and future tourism behavior. Prayag ${ }^{55}$ shared similar findings indicating that satisfaction and overall image play a mediating role between destination image and future behavior.

Although image perceptions are important in forming tourists' future intentions, destination personality is a closer measure. A recent study conducted by $\mathrm{Xie}^{17}$ supported the assertion of indirect effect of destination image on tourists' behavioral intentions through destination personality. She also argued that three dimensions of destination personality (competence, sophistication, and excitment) are indicators of tourist behavioral intentions; competence directly encourage tourists' willingness to pay more, sophistication works better in driving tourists' comments, and excitement works well in driving word-of-mouth intentions.

Using a sample of 361 urban tourists that included both past visitors and non-visitors of the urban destination under study, data analysis confirmed the influential role of destination personality and affective image in the formation of overall destination image in both samples. In turn, overall image was a mediator of the relationships of destination personality and affective image with tourists' behavioral intentions (i.e., intention to revisit the urban destination and intention to recommend the destination to others). Analysis of the data supported a two-factor solution of the destination personality construct, with the personality traits of sincerity and excitement emerging in the domestic urban context to influence past visitors' and non-visitors' overall destination image perceptions. ${ }^{56}$

Based on the above discussion and in order to respond to the research questions, this study postulated the following group of hypotheses:

H1: Perceived cognitive destination image has a significant positive effect on purchase intentions.

H2: Perceived cognitive destination image has a significant positive impact on word-of-mouth intentions.

H3: Perceived affective destination image has a significant positive impact on purchase intentions.

H4: Perceived affective destination image has a significant positive impact on word-of-mouth intentions.

H5: Perceived destination personality has a significant positive impact on purchase intentions.

H6: Perceived destination personality has a significant positive impact on word-of-mouth intentions.

H7: Destination personality has a mediating effect on the relationship between destination image and behavioral intentions.

\section{METHOD}

\section{Research Design and Measurement}

The study adopted a quantitative paradigm as it meets adequately the theoretical framework and the research model. The key features used to support quantitative approach during this study are: (1) a survey questionnaire was used for data collection; (2) the sample is large and representative for the population being studied; (3) statistical analysis was used to draw conclusions; (4) closed questions are asked to get specific answer; and (5) opinions were measured by scoring and rating scale (a 7-point scale). Moreover, it is considered to be empirical in nature due to using a survey to test the research model and respond to the research questions. Also, the research design can be considered as causal-effect research as it tried to investigate and tests hypotheses about cause and effect relationships.

Based on a close examination of literature 1757585960 , a measure was developed for assessing cognitive destination image. The initial format was consisted of 4 dimensions (natural attributes, constructed attributes, environment aspects, and local people) and 47 indicators using a 7-point interval scale (where $1=$ extremely poor, 2 = very poor, $3=$ somewhat poor, $4=$ neutral, 5 = somewhat good, $6=$ very good, and $7=$ extremely good). The model of Russell et al. (1981) was accepted to measure tourist's affective destination image on a 7 -point scale $(1=$ very strong, $2=$ strong, $3=$ some, $4=$ neutral, $5=$ some, $6=$ strong, and $7=$ very strong). This model contained two bipolar affective image dimensions: (1) Pleasant-unpleasant and arousing-sleepy dimension, and (2) Exciting-gloomy and relaxing-distressing dimension. 
By adapting Brand Personality Scale (BPS) developed by Aaker ${ }^{30}$, a measure was developed to assess destination personality. This measure consisted of 5 dimensions (sincerity, excitement, competence, sophistication, ruggedness) and 20 traits using a 7 -point scale (where $1=$ not descriptive at all, $2=$ not descriptive, $3=$ somewhat not descriptive, $4=$ neutral, $5=$ somewhat descriptive, $6=$ descriptive, and $7=$ extremely descriptive). The behavioral intentions measure developed by Zeithamle, Berry and Parasuraman ${ }^{42}$ was accepted in this study. This measure includes two dimensions (purchase intentions and word-of-mouth (WoM) intentions) and six indicators using a 7-point Likert scale ranging from (1) totally disagree to (7) totally agree.

Finally, a preliminary questionnaire was developed using self-administrated format. The questionnaire was designed in English language to measure all variables and consisted of 5 sections. Sections I to IV included measurements of cognitive destination image, affective destination image, destination personality, and behavioral intentions. Section V was developed to obtain the demographic profile of respondents. The questions about respondents' demographic profile concerned with: Gender, age, marital status, and education.

\section{Data Collection and Analysis}

In line with the quantitative nature of this study, the data was collected through conducting a survey. A random sample of 300 foreign tourists to Oman was arranged for research model and hypotheses testing during the period of September 2013 to December 2013. The study followed a two-step approach as recommended by Anderson and Gerbing ${ }^{61}$ to analyze data collected in the present study. The first step in this approach is to develop an acceptable measurement model before depending on this model to predict causal relationships among the study variables. To develop an acceptable measurement model, exploratory factor analysis (EFA) and confirmatory factor analysis (CFA) were performed with employing validity and reliability tests. While EFA used the data collected during the pilot study, CFA used basic data collected from the main sample. EFA was conducted through running SPSS 19, while CFA was conducted through AMOS 22 software. Validity and reliability tests were calculated using AMOS. Moreover, descriptive analysis was conducted for data screening and normality testing. Finally, the second step was conducted by testing the structural model using AMOS software.

\section{Pilot Test}

The questionnaire was pre-tested using a random sample of 200 foreign and domestic tourists in Oman (80\% response rate) to assess the operationalization feasibility of the survey approach. Male respondents accounted for $75.6 \%$ of total respondents and female accounted for $24.4 \%$ of total respondents. The majority of the respondents (81.9\%) were married. Majority of respondents received tertiary education at undergraduate level $(57.5 \%)$ or higher $(11.9 \%)$. Regarding traveler type, foreign tourists accounted for $42.5 \%$ and domestic tourists accounted for $57.5 \%$.

For approving the initial form of the questionnaire before distributing to the main sample, an exploratory factor analysis (EFA) was conducted. EFA was running only for cognitive image construct as it is the only construct which was developed by the author based upon close examination of the related literature review. Regarding the remaining constructs investigated in the present study, which were adopted from literature review, they were not employed to EFA but to CFA instead. A previous study for the author ${ }^{16}$ indicated complete details about the procedures and output of EFA of cognitive image construct. From EFA output, only four factors were extracted and 35 items have factor loadings more than 0.4. Seven items have been dropped during analysis due to their factor loadings are less than 0.4. Regarding the four factors extracted, the first factor included seven items and was renamed as "Health and Social Attributes (HSA)". The second factor included eight items and its name was remained the same "Constructed Attributes (CA)". The third factor included thirteen items and its name was remained the same "Environmental Attributes (EA)". The fourth factor included seven items and was renamed "Local People and Natural Attributes (LNA)".

\section{RESULTS}

\section{Data Screening}

The survey was conducted with the assistance of hotels and travel agencies within Salalah and Muscat. The number questionnaires distributed to tourists were 300, among which 269 questionnaires were returned, which represent a response rate of $89.7 \%$. Among the 269 returned questionnaires, 239 questionnaires were finished entirely. However, this was not the valid sample size for overall measurement and structural model testing. It was found that in addition to double checks for the same items in some questionnaires, a group of items had all been doubtfully checked consecutively with the same point on the scale. As a result, 16 dubious cases had been eliminated. The remaining 223 cases were finally used as the validate dataset for the analysis.

After variables' coding and variable file preparing using SPSS program, all responses were entered. The first step of data screening was dealing with missing data. Missing value analysis was conducted and the results indicated some few missing 
data that had been handled. Outlier exclusion analysis was also conducted to identify extreme data. Only few cases were observed and handled. As per the importance of normality distribution in parametric analysis, data normality tests were used to determine whether a dataset is well-modeled by a normal distribution or not. Two methods are used to test the normality of data distribution: Kolmogrov-Smirnov (K-S) test, and Shapiro-Wilk (S-W) test. Results ensured the normality of data distribution for all constructs and items, where all K-S statistics and S-W statistics are significance at $95 \%$ confidence interval for all items (table 5).

\section{Respondents' demographic profile:}

The inbound tourist profile of 223 respondents is shown in table (3). Respondents consist of more male tourists $(72.6 \%)$ than female tourists $(27.4 \%)$. The majority of the respondents are between the ages $41-50$, which accounts for $43.5 \%$ of the total respondents. The second largest group of respondents is those between 31-40 representing 21.5\% of the total respondents. The age of the remaining respondents are distributed among the age group of 21-30 (16.6\%), 51-60 (12.6), and the least respondents in the upper $(61$ and above $(3.1 \%))$ and lower (20 and under (2.7\%)) age groups. Regarding the education level, most of the respondents hold the degree of bachelor (45.7\%) and master degree (22.4). Holders of associate degree/technical certificates account for $16.6 \%$ among the total respondents. Respondents with the lowest education level (high school or less) represent 9.9\%, and those with the highest $\mathrm{PhD} /$ doctoral represent $5.4 \%$ of the total respondents.

Table (3): Demographic profile of respondents $(n=223)$

\begin{tabular}{|c|c|c|c|c|c|}
\hline $\begin{array}{l}\text { Demographic } \\
\text { Variables }\end{array}$ & Frequency $(\mathbf{N})$ & $\begin{array}{l}\text { Percent } \\
(\%)\end{array}$ & Demographic Variables & Frequency $(\mathbf{N})$ & $\begin{array}{l}\text { Percent } \\
(\%)\end{array}$ \\
\hline Gender & & & Marriage & & \\
\hline Male & 162 & 72.6 & Single & 45 & 20.2 \\
\hline \multirow[t]{2}{*}{ Female } & 61 & 27.4 & Married & 175 & 78.5 \\
\hline & & & Other & 3 & 1.3 \\
\hline \multicolumn{6}{|l|}{ Age } \\
\hline 20 and Under & 6 & 2.7 & Education & & \\
\hline $21-30$ & 37 & 16.6 & High school or less & 22 & 9.9 \\
\hline $31-40$ & 47 & 21.5 & $\begin{array}{l}\text { Associate degree/ technical } \\
\text { certificate }\end{array}$ & 37 & 16.6 \\
\hline $41-50$ & 97 & 43.5 & Bachelor's Degree & 102 & 45.7 \\
\hline $51-60$ & 28 & 12.6 & Master's Degree & 50 & 22.4 \\
\hline 61 and Above & 7 & 3.1 & Ph.D/ Doctoral & 12 & 5.4 \\
\hline
\end{tabular}

\section{Measurement Model}

Testing the dimensionality of measurement model

Confirmatory Factor Analysis (CFA) is the next step after EFA to determine the factor structure of the dataset. In the EFA, the decision is to explore the factor structure (how the variables relate and group based on inter-variable correlations); in the CFA, the decision is to confirm the factor structure that extracted in the EFA. ${ }^{62}$

To develop an acceptable measurement model for each construct under study, the model is first specified (based on a theory) and then the sample data is utilized to test the model to determine the goodness-of-fit (GOF) between the hypothesized model and the sample data. The three Byrne's models ${ }^{63}$ were performed and tested using CFA to extract the valid measurement model for each construct. The first model, all the study indicators might be tested to find out if they 
might be allowed to be freely correlated (oblique factor model or multidimensional model). The second model, all factors may be correlated with the higher-order construct (higher order factor model or second order undimensional model). The third model can be employed to measure only one related construct (one factor model or undimesnional model).

To assess the valid measurement model, a CFA was firstly conducted on the overall sample data $(\mathrm{n}=223)$ using AMOS 22.0 with the maximum likelihood estimation method. Since the Chi-square statistic is highly sensitive to sample size ${ }^{62}$, three alternative GOF measures (absolute fit, incremental fit, and parsimony fit measures) were employed as recommended by Hair, Black, Babin and Anderson ${ }^{62}$. Model fit indices of $\chi 2 / \mathrm{df}$, SRMR and RMSEA were used as measures of absolute fit. CFI, NFI and GFI were used to assess incremental fit. PCFI and PNFI were used to measure the parsimony fit. ${ }^{6263}$

From AMOS output indicated in table 4, the statistics of fit indices implied that all the valid measurement models' fit is quite reasonably adequate for further analysis. While the p-values of chi-square index of most measurement models support the rejection of null hypothesis, indicating poor model fit and possible rejection of the model, the alternative indices indicated satisfactory model fit. For all valid measurement models, the values of the Standardized Root Mean Square Residual (SRMR) are below the threshold value of 0.09, the values of Root Mean Square Error of Approximation (RMSEA) are good $(\leq 0.05)$, and the values of CFI, NFI, and GFI exceed the cut-off value of 0.9 as recommended by Hair, Black, Babin and Anderson. ${ }^{62}$

Table (4): Goodness-of-fit of the measurement model $(n=223)$

\begin{tabular}{lllllll}
\hline Model & P-Value & SRMR & RMSEA & CFI & NFI & GFI \\
\hline & $\mathbf{> 0 . 0 5}$ & $\leq \mathbf{0 . 0 9}$ & $\leq \mathbf{0 . 0 5}$ & $\mathbf{2 0 . 9}$ & $\mathbf{2 0 . 9}$ & $\mathbf{2 0 . 9}$ \\
\cline { 2 - 6 } & .000 & .088 & .041 & .982 & .918 & .933 \\
Cognitive Image (CI) & .000 & .078 & .032 & .912 & .908 & .955 \\
Affective Image (AI) & .951 & .042 & .000 & .1 .00 & .763 & .954 \\
Destination Personality (DP) & .000 & .001 & .041 & 1.00 & 1.00 & 1.00 \\
Purchase Intentions (PI) & .000 & .001 & .039 & 1.00 & 1.00 & 1.00 \\
Word-of-Mouth Intentions (WI) & & &
\end{tabular}

SRMR = Standardized Root Mean Square Residual; RMSEA = Root Mean Square Error of Approximation; CFI = Comparative Fit Index; NFI = Normed-Fit Index; GFI = Goodness of Fit Index.

As the confirmatory factor analysis suggests that the measurement model for cognitive image construct is multidimensional model or oblique factor model. Based upon the modification indices suggested by AMOS, the four factors of cognitive image construct extracted from EFA were reduced to only three factors. These factors are presented in table 5 and titled as "Health and Social Attributes (HSA)", "Constructed Attributes (CNA)", and "Environmental Attributes (ENA)". The items of the fourth factor extracted from EFA (Local People and Natural Attributes 'LNA') were merged with HSA and ENA factors. As indicated in table 5, five items were shifted to HSA factor, and two items were shifted to ENA factor. The final measurement model of cognitive construct showed two items with standard loadings which are less than 0.30 (table 4), therefore these items were deleted in the SEM model as recommended by Hair et al. (2010). These items are: "Ethics of fair trade (LNA5)", and "Charm of mountains (LNA7)". In response to the modification indices suggested by AMOS, one environmental attribute titles as "Energy conserving (ENA5)" was shifted to constructed attributes factor. As shown in table 5, the final measurement model includes 12 health and social attributes, 7 constructed attributes, and 14 environmental attributes with significant standardized factor loadings for all attributes.

Table (5): Normality Tests and Results of Confirmatory Factor Analysis ( $=223)$

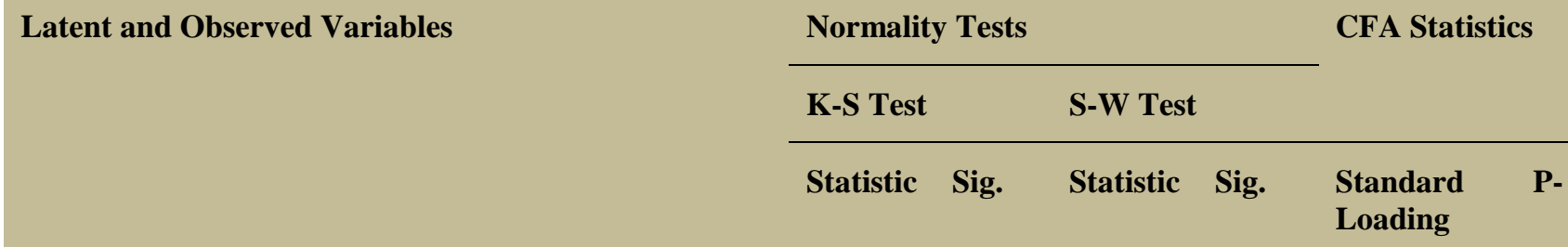




\section{Cognitive Image}

HSA Health and Social Attributes

\begin{tabular}{|c|c|c|c|c|c|c|}
\hline HSA1 & Social harmony & 0.263 & 0.000 & 0.802 & 0.000 & $0.650^{* * *}$ \\
\hline HSA2 & Ability of local service & 0.236 & 0.000 & 0.820 & 0.000 & $0.455^{* * *}$ \\
\hline HSA3 & Control of disease & 0.274 & 0.000 & 0.828 & 0.000 & $0.505^{* * *}$ \\
\hline HSA4 & Reasonableness of price & 0.194 & 0.000 & 0.889 & 0.000 & $0.415^{* * *}$ \\
\hline HSA5 & Hard-working attitude of local people & 0.285 & 0.000 & 0.859 & 0.000 & $0.453^{* * *}$ \\
\hline HSA6 & Availability of travel information & 0.194 & 0.000 & 0.892 & 0.000 & $3.770^{*}$ \\
\hline HSA7 & Food safety and hygiene & 0.276 & 0.000 & 0.802 & 0.000 & $0.467^{* * *}$ \\
\hline CNA5 & Local transportation & 0.251 & 0.000 & 0.878 & 0.000 & $0.343^{* * * *}$ \\
\hline CNA7 & Entertainment opportunities & 0.262 & 0.000 & 0.875 & 0.000 & $0.302^{* * *}$ \\
\hline LNA1 & Honesty and trustworthiness of local people & 0.224 & 0.000 & 0.850 & 0.000 & $0.316^{* * *}$ \\
\hline LNA2 & Local people' willingness to help tourist & 0.197 & 0.000 & 0.867 & 0.000 & $0.382^{*}$ \\
\hline LNA3 & $\begin{array}{l}\text { Friendliness and courteousness of local } \\
\text { people }\end{array}$ & 0.214 & 0.000 & 0.831 & 0.000 & $0.397^{*}$ \\
\hline LNA5 & Ethics of fair trade & 0.207 & 0.000 & 0.912 & 0.000 & -0.047 \\
\hline LNA7 & Charm of mountains & 0.209 & 0.000 & 0.900 & 0.000 & 0.009 \\
\hline
\end{tabular}

\section{CNA Constructed Attributes}

$\begin{array}{llllllll}\text { CNA1 } & \text { Ease of communication with local people } & 0.214 & 0.000 & 0.883 & 0.000 & 0.682^{* * * *} & 0.000 \\ \text { CNA2 } & \text { Variety of heritage attractions } & 0.220 & 0.000 & 0.882 & 0.000 & 0.656^{* * * *} & 0.000 \\ \text { CNA3 } & \text { Accommodation } & 0.224 & 0.000 & 0.886 & 0.000 & 0.570^{* * * *} & 0.000 \\ \text { CNA4 } & \text { Local infrastructure } & 0.224 & 0.000 & 0.874 & 0.000 & 0.502^{* * *} & 0.000 \\ \text { CNA6 } & \text { Variety of cultural activities } & 0.358 & 0.000 & 0.721 & 0.000 & 0.523^{* * *} & 0.000 \\ \text { CNA8 } & \text { Restaurant } & 0.244 & 0.000 & 0.896 & 0.000 & 0.549^{* *} & 0.003 \\ \text { ENA5 } & \text { Energy conserving } & 0.281 & 0.000 & 0.821 & 0.000 & 0.502^{* * *} & 0.000\end{array}$




\begin{tabular}{|c|c|c|c|c|c|c|}
\hline ENA1 & Nature conservation & 0.230 & 0.000 & 0.895 & 0.000 & $0.523^{* * *}$ \\
\hline ENA2 & Control of overcrowding at public areas & 0.217 & 0.000 & 0.901 & 0.000 & $0.574^{* * * *}$ \\
\hline ENA3 & Environmental awareness of local residents & 0.259 & 0.000 & 0.793 & 0.000 & $0.480^{* * *}$ \\
\hline ENA4 & Tourist safety and security & 0.199 & 0.000 & 0.875 & 0.000 & $0.488^{* *}$ \\
\hline ENA6 & Overall environmental management & 0.229 & 0.000 & 0.878 & 0.000 & $0.662^{* * *}$ \\
\hline ENA7 & Obedience to social regulations & 0.212 & 0.000 & 0.879 & 0.000 & $0.563^{*}$ \\
\hline ENA8 & Air quality & 0.304 & 0.000 & 0.779 & 0.000 & $0.435^{* * *}$ \\
\hline ENA9 & Practice of using few plastic bags & 0.178 & 0.000 & 0.884 & 0.000 & $0.464^{*}$ \\
\hline ENA10 & Waste and garbage disposal & 0.236 & 0.000 & 0.815 & 0.000 & $0.540^{* * *}$ \\
\hline ENA11 & Control of noise & 0.222 & 0.000 & 0.887 & 0.000 & $0.436^{* * *}$ \\
\hline ENA12 & Control of emissions & 0.255 & 0.000 & 0.832 & 0.000 & $0.471^{*}$ \\
\hline ENA13 & Political stability & 0.201 & 0.000 & 0.879 & 0.000 & $0.486^{* *}$ \\
\hline LNA4 & Overall scenic beauty & 0.214 & 0.000 & 0.880 & 0.000 & $0.407^{*}$ \\
\hline LNA6 & Clearness of sky & 0.195 & 0.000 & 0.902 & 0.000 & $0.548^{* * * *}$ \\
\hline
\end{tabular}

\section{AFFECTIVE IMAGE}

$\begin{array}{llllllll}\text { AI1 } & \text { Unpleasant-Pleasant } & 0.242 & 0.000 & 0.803 & 0.000 & 0.535^{* * * *} & 0.000 \\ \text { AI2 } & \text { Sleepy-Arousing } & 0.168 & 0.000 & 0.948 & 0.000 & 0.506^{* * *} & 0.000 \\ \text { AI3 } & \text { Distressing-Relaxing } & 0.228 & 0.000 & 0.860 & 0.000 & 0.569^{* * *} & 0.000 \\ \text { AI4 } & \text { Gloomy-Exciting } & 0.167 & 0.000 & 0.932 & 0.000 & 0.517^{* * *} & 0.000\end{array}$

\section{DESTINATION PERSONALITY}

\section{DPS Sincerity}

$\begin{array}{llllllll}\text { DPS1 } & \text { Domestic } & 0.278 & 0.000 & 0.790 & 0.000 & 0.780^{* * *} & 0.000 \\ \text { DPS2 } & \text { Honest } & 0.299 & 0.000 & 0.756 & 0.000 & 0.631^{*} & 0.011 \\ \text { DPS3 } & \text { Genuine } & 0.212 & 0.000 & 0.819 & 0.000 & 0.599^{*} & 0.028 \\ \text { DPS4 } & \text { Cheerful } & 0.270 & 0.000 & 0.816 & 0.000 & 0.581^{*} & 0.026\end{array}$

DPE Excitement 


\begin{tabular}{|c|c|c|c|c|c|c|c|}
\hline DPE1 & Daring & 0.321 & 0.000 & 0.766 & 0.000 & $0.883^{* * *}$ & 0.000 \\
\hline DPE2 & Spirited & 0.382 & 0.000 & 0.691 & 0.000 & $0.650^{*}$ & 0.038 \\
\hline DPE3 & Imaginative & 0.192 & 0.000 & 0.827 & 0.000 & $0.580^{*}$ & 0.027 \\
\hline DPE4 & Up-to-date & 0.197 & 0.000 & 0.869 & 0.000 & $0.418^{*}$ & 0.038 \\
\hline DPC & Competence & & & & & & \\
\hline DPC1 & Reliable & 0.217 & 0.000 & 0.872 & 0.000 & $0.541^{* * * *}$ & 0.000 \\
\hline DPC2 & Responsible & 0.190 & 0.000 & 0.863 & 0.000 & $0.553^{* * * *}$ & 0.001 \\
\hline DPC3 & Dependable & 0.221 & 0.000 & 0.873 & 0.000 & $0.507^{* * * *}$ & 0.000 \\
\hline DPC4 & Efficient & 0.235 & 0.000 & 0.873 & 0.000 & $0.535^{* * * *}$ & 0.001 \\
\hline DPO & Sophistication & & & & & & \\
\hline DPO1 & Glamorous & 0.212 & 0.000 & 0.874 & 0.000 & $0.654^{* * * *}$ & 0.000 \\
\hline DPO2 & Pretentious & 0.249 & 0.000 & 0.867 & 0.000 & $0.521^{*}$ & 0.025 \\
\hline DPO3 & Charming & 0.210 & 0.000 & 0.880 & 0.000 & $0.554^{*}$ & 0.049 \\
\hline DPO4 & Romantic & 0.209 & 0.000 & 0.874 & 0.000 & $0.559^{*}$ & 0.036 \\
\hline DPR & Ruggedness & & & & & & \\
\hline DPR1 & Tough & 0.211 & 0.000 & 0.840 & 0.000 & $0.632^{* * * *}$ & 0.000 \\
\hline DPR2 & Strong & 0.213 & 0.000 & 0.819 & 0.000 & $0.523^{* * *}$ & 0.001 \\
\hline DPR3 & Outdoorsy & 0.259 & 0.000 & 0.817 & 0.000 & $0.447^{*}$ & 0.019 \\
\hline DPR4 & Rugged & 0.263 & 0.000 & 0.776 & 0.000 & $0.523^{* *}$ & 0.007 \\
\hline
\end{tabular}

\section{Purchase Intentions}

$\begin{array}{llllllll}\text { PI1 I am willing to pay more for visiting Oman } & 0.236 & 0.000 & 0.900 & 0.000 & 0.691 * * * & 0.000 \\ \text { PI2 } \quad \begin{array}{l}\text { I am willing to purchase more tourism } \\ \text { products in Oman }\end{array} & 0.201 & 0.000 & 0.906 & 0.000 & 0.512 * * * & 0.000 \\ \text { PI3 } \quad \begin{array}{l}\text { I will pay higher price to visit Oman despite } \\ \text { other competing destinations' price lower }\end{array} & 0.218 & 0.000 & 0.888 & 0.000 & 0.524 * * * & 0.000\end{array}$

\section{Word-of-Mouth intentions}

WI1 I will encourage friends and relatives to visit 
Oman

$\begin{array}{llllllll}\text { WI2 I will say positive things about Oman to other } & 0.218 & 0.000 & 0.898 & 0.000 & 0.676^{*} & 0.032 \\ \text { people } & & & & & & & \\ \text { WI3 } \quad \begin{array}{l}\text { I will recommend Oman to anyone who seeks } \\ \text { my advice }\end{array} & 0.225 & 0.000 & 0.888 & 0.000 & 0.543^{* *} & 0.010 \\ & & & & & & \end{array}$

$C R=$ Composite Reliability; $A V E=$ Average Variance Extracted .

$* p \leq 0.05 ; * * p \leq 0.01 ; * * * p \leq 0.001$.

The result of CFA approved the multidimensional model for destination personality construct. Five dimensions (sincerity, excitement, competence, sophistication, ruggedness) were extracted as those identified by Aaker ${ }^{30}$. As indicated in table 5, twenty items appeared significant factor loadings on the five factors identified. Regarding affective image, purchase intentions, and word-of-mouth intentions constructs, undimensional or one factor models were identified and validated by CFA. Four items were significantly loaded for affective image construct, and three items were significantly loaded for either purchase intentions construct or word-of-mouth construct.

\section{Testing the validity and reliability of measurement model}

As an important preliminary step in the analysis of full latent variable models, the validity and reliability of the measurement model were tested using CFA in AMOS. Validity refers to the extent to which all observed items properly represent their respective latent construct. ${ }^{63}$ According to Campbell and Fiske ${ }^{64}$, there are two main components of construct validity: convergent and discriminant validity.

Convergent validity is the extent to which the latent variable correlates to indicators pre-specified to measure the same construct. ${ }^{61}$ Convergent validity was assessed through calculating composite reliability (CR) and average variance extracted (AVE). While CR refers to the internal consistency of the measured variables representing a latent construct, AVE reflects the overall amount of variance in the observed variables accounted for by the latent construct (Hair et al., 2010). ${ }^{62}$ As shown in table 6, the values for CR and AVE for all constructs under study have exceeded the required value which is 0.7 above for CR and 0.5 above for AVE as suggested by Hair, Black, Babin and Anderson. ${ }^{62}$ Therefore, all constructs investigated in the present study have adequate convergent validity.

Discriminant validity is defined as the extent to which indicators of a construct are distinct from the items of other latent variables. ${ }^{62}$ Fornell and Larcker ${ }^{65}$ suggested that discriminant validity is established when the square root of AVE for each construct is greater than the correlation coefficient between the construct and all remaining constructs in the model. Table 6 shows the interconstruct correlations in the lower triangle of the matrix and square root of AVE on the diagonal of the matrix. As all the construct correlations are smaller than the square roots of AVE, it is concluded that all the constructs meet the discriminant validity requirement. Subsequently, the structural path model can be assessed to examine the proposed hypotheses.

Cronbach's alpha is commonly used to establish the internal consistency construct validity. Construct reliability values of 0.70 or higher indicate good reliability, and between 0.60 and 0.70 is acceptable. ${ }^{62}$ As indicated in table 6 , all the Cronbach's alpha values of all constructs are above 0.70 except three constructs which have value between 0.60 and 0.70 . Similarly, the estimates of composite reliability (ranged between 0.701 and 0.931 ) were all above the recommended threshold of 0.70 of Hair, Black, Babin and Anderson. ${ }^{62}$. Therefore, the reliability was established. 
Table (6): Correlation Matrix, Reliability, Convergent Validity and Discriminant Validity Analysis for all constructs (n= 223)

\begin{tabular}{|c|c|c|c|c|c|c|c|c|c|c|c|c|c|}
\hline & COIMG & HSA & CNA & ENA & AFIMG & DPERS & DPS & DPE & $\mathrm{DPC}$ & DPO & DPR & PI & WI \\
\hline Cognitive Image (COIMG) & 0.745 & & & & & & & & & & & & \\
\hline $\begin{array}{l}\text { Health and Social Attributes } \\
\text { (HSA) }\end{array}$ & .682 & 0.840 & & & & & & & & & & & \\
\hline Constructed Attributes (CNA) & .605 & .258 & 0.754 & & & & & & & & & & \\
\hline Environmental Attributes (ENA) & .705 & .339 & .525 & 0.711 & & & & & & & & & \\
\hline Affective Image (AFIMG) & 0.102 & 0.047 & -0.012 & -0.062 & 0.729 & & & & & & & & \\
\hline Destination personality (DPERS) & .339 & .194 & .226 & 0.031 & .478 & 0.764 & & & & & & & \\
\hline Sincerity (DPS) & 0.077 & 0.023 & 0.078 & 0.03 & .373 & .323 & 0.805 & & & & & & \\
\hline Excitement (DPE) & .269 & .184 & 0.036 & -0.005 & .266 & .575 & 0.063 & 0.796 & & & & & \\
\hline Competence (DPC) & .192 & 0.119 & .256 & 0.019 & .184 & .566 & 0.038 & -0.019 & 0.731 & & & & \\
\hline Sophistication (DPO) & .239 & 0.069 & .271 & .152 & .178 & .436 & -0.057 & -0.011 & .214 & 0.756 & & & \\
\hline Ruggedness (DPR) & -0.091 & -0.024 & -.178 & -0.119 & 0.118 & .236 & -0.005 & 0.056 & -.216 & -.168 & 0.729 & & \\
\hline Purchase Intentions (PI) & .315 & .314 & .186 & .292 & 0.07 & .236 & 0.041 & 0.089 & .197 & .274 & -0.118 & $\begin{array}{r}0.75 \\
9\end{array}$ & \\
\hline Word-of-Mouth Intentions (WI) & .378 & .282 & .328 & .410 & 0.124 & .206 & 0.097 & 0.127 & .142 & .157 & -0.088 & .478 & 0.795 \\
\hline Composite Reliability (CR) & 0.930 & 0.864 & 0.757 & 0.802 & 0.706 & 0.931 & 0.807 & 0.706 & 0.715 & 0.712 & 0.701 & $\begin{array}{r}0.72 \\
7\end{array}$ & 0.723 \\
\hline $\begin{array}{l}\text { Average Variance Extracted } \\
\text { (AVE) }\end{array}$ & 0.558 & 0.705 & 0.569 & 0.506 & 0.532 & 0.584 & 0.648 & 0.633 & 0.534 & 0.572 & 0.531 & $\begin{array}{r}0.57 \\
6\end{array}$ & 0.632 \\
\hline 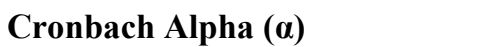 & 0.753 & 0.745 & 0.628 & 0.721 & 0.757 & 0.758 & 0.648 & 0.727 & 0.805 & 0.649 & 0.606 & 754 & 0.730 \\
\hline
\end{tabular}


Note: Square root of average variance extracted (AVE) is shown on the diagonal of the matrix (boldfaced entries); interconstruct correlations are shown off the diagonal. 


\section{Structural Model}

The causal relationships between destination brand and behavioral intentions

Structural equation modeling (SEM) has been frequently used in psychology and social sciences because it enables researchers to assess and modify theoretical models. ${ }^{66}$ According to Anderson and Gerbing ${ }^{61}$, structural testing involves a two-stage process. The first stage ensures good measurement of the constructs while the second involves an assessment of the causal relationships. Testing the measurement was conducted using CFA in the previous section. The output of CFA showed an acceptable measurement model with satisfied validity and reliability. SEM analysis was conducted using SPSS AMOS to test the proposed theoretical model and hypotheses.

For testing the first six hypotheses, two structural models were proposed. The first model is a four-construct model that includes four causal relations or paths: (1) from cognitive destination image as exogenous variable to purchase intentions as endogenous variable; (2) from cognitive destination image as exogenous variable to word-of-mouth intentions as endogenous variable; (3) from affective destination image as exogenous variable to purchase intentions as endogenous variable; and (4) from affective destination image as exogenous variable to word-of-mouth intentions as endogenous variable.

The first step with SEM is running some descriptive fit statistics to assess the overall fit of the first model to data. As indicated in table (7), the structural model revealed a significant chi-square statistics $(\chi 2=40.09$, p-value $<0.01)$. To obtain a superior goodness of fit, a modification index was conducting and minor modifications on the research model diagram were done. The descriptive model-fit statistics ensured that the overall model fit is quite reasonably adequate for further analysis. The goodness of fit index $(\mathrm{GFI}=0.924)$, the comparative fit index $(\mathrm{CFI}=0.980)$, and the incremental fit index $(\mathrm{IFI}=0.918)$ are over 0.90 for satisfactory model fit. Therefore, the causal relationships could be examined within the fully accepted model.

Table (7): Descriptive Fit Statistics of the proposed model $(n=223)$

\begin{tabular}{|c|c|c|c|c|c|}
\hline & \multicolumn{2}{|l|}{ Chi Square $\left(\chi^{2}\right)$} & \multirow[t]{2}{*}{ GFI } & \multirow[t]{2}{*}{ CFI } & \multirow[t]{2}{*}{ IFI } \\
\hline & $\chi^{2}$ Statistics & P-value & & & \\
\hline The 1st Model (Four-Construct Model) & 40.09 & 0.000 & 0.924 & 0.980 & 0.918 \\
\hline The 2nd Model (Three-Construct Model) & 50.65 & 0.000 & 0.980 & 0.910 & 0.911 \\
\hline The 3rd Model (Three-Construct Model) & 0.007 & 0.911 & 1.000 & 1.000 & 1.000 \\
\hline The 4th Model (Five-Construct model) & 39.492 & 0.000 & 0.939 & 0.988 & 0.998 \\
\hline
\end{tabular}

GFI = goodness of fit index $; C F I=$ comparative fit index; $I F I=$ incremental fit index.

Table (8) shows the standardized coefficients for the effects of exogenous variable on the endogenous variables for the first model. As could be observed from table (8), the first two hypotheses are supported at $0.1 \%$ confidence interval. Cognitive destination image has a significant positive effect on both purchase intentions $(\beta=0.311$, $p$ value $<0.001)$, and word-of-mouth intentions $(\beta=0.373, p$-value $<0.001)$. It is implied that as cognitive destination image increase by one standard deviation, purchase intentions will increase by 0.311 standard deviations, and wordof mouth will increase by 0.373 standard deviations. On the other hand, the results revealed no evidence to support the $3^{\text {rd }}$ and $4^{\text {th }}$ hypotheses. Not only affective destination image has weak positive influences on both purchase intentions $(\beta=0.038, p$-value $=0.550)$ and word-of-mouth intentions $(\beta=0.091$, p-value $=0.144)$, but also these influences are not significant. Also, the results indicate that both cognitive and affective images are responsible for $10.1 \%$ of changes in purchase intentions, and $15.4 \%$ of changes in word-of-mouth intentions. 
Table (8): Results of the four proposed models

\begin{tabular}{llllll}
\hline Exogenous Variables & $\begin{array}{l}\text { Path } \\
\text { To }\end{array}$ & Endogenous Variables & $\begin{array}{l}\text { Standardized } \\
\text { Regression } \\
\text { Coefficient } \\
(\beta)\end{array}$ & $\begin{array}{l}P \text { value } \\
\text { valu }\end{array}$ & $R^{2}$ \\
& & Hypotheses & \\
\hline
\end{tabular}

\section{$\underline{\text { The } 1^{\text {st }} \text { Model (Four-Construct Model) }}$}

Cognitive image $(2,4)^{\mathrm{a}} \quad \rightarrow \quad$ Purchase Intentions $\quad 0.311 * * *^{\mathrm{b}} \quad 0.000 \quad 0.101 \quad$ H1: Supported

$\begin{array}{llllll}\text { Affective image }(2,4) & \rightarrow & \text { Purchase Intentions } & 0.038 & 0.550 \quad \text { H3: }\end{array}$

Supported
Sur

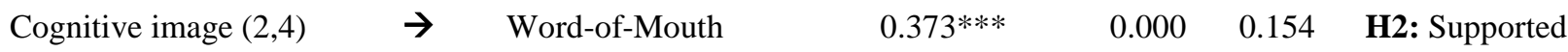
Intentions

Affective image $(2,4)$

$\rightarrow \quad \begin{aligned} & \text { Word-of-Mouth } \\ & \text { Intentions }\end{aligned}$

$0.091 \quad 0.144$

H4: Not Supported

The $2^{\text {nd }}$ Model (Three-Construct Model)

$\begin{array}{lllllll}\text { Destination Personality } & \rightarrow & \text { Purchase Intentions } & 0.236^{* * *} & 0.000 & 0.056 & \text { H5: Supported } \\ \text { Destination Personality } & \rightarrow & \begin{array}{l}\text { Word-of-Mouth } \\ \text { Intentions }\end{array} & 0.206^{* *} & 0.002 & 0.043 & \text { H6: Supported }\end{array}$

\section{The $3^{\text {rd }}$ Model (Three-Construct Model)}

Cognitive image (1) $\quad \rightarrow \quad$ Destination personality

$0.294 * * * \quad 0.000 \quad 0.314$

Affective image (1)

$\rightarrow \quad$ Destination personality

$0.448 * * * \quad 0.000$

\section{The $4^{\text {th }}$ Model (Five-Construct model)}

$\begin{array}{llllll}\text { Cognitive image }(3,4) & \rightarrow & \text { Purchase Intentions } & 0.263^{* * *} & 0.000 & 0.119 \\ \text { Affective image }(3,4) & \rightarrow & \text { Purchase Intentions } & -0.035 & 0.626 \\ \begin{array}{l}\text { Destination Personality } \\ (3, \mathrm{~m})\end{array} & \rightarrow & \text { Purchase Intentions } & 0.164^{*} & 0.031 \\ \text { Cognitive image }(3,4) & \rightarrow & \begin{array}{l}\text { Word-of-Mouth } \\ \text { Intentions }\end{array} & 0.356^{* * *} & 0.000 & 0.157 \\ \text { Affective image }(3,4) & \rightarrow & \begin{array}{l}\text { Word-of-Mouth } \\ \text { Intentions }\end{array} & 0.065 & 0.358\end{array}$




$\begin{array}{llllll}\begin{array}{l}\text { Destination Personality } \\ (3, \mathrm{~m})\end{array} & \rightarrow & \begin{array}{l}\text { Word-of-Mouth } \\ \text { Intentions }\end{array} & 0.058 & 0.436 & \\ \text { Cognitive image (m) } & \rightarrow & \text { Destination personality } & 0.294^{* * *} & 0.000 & 0.314 \\ \text { Affective image (m) } & \rightarrow & \text { Destination personality } & 0.448^{* * *} & 0.000 & \end{array}$

a Numbers in parentheses indicate the followings: $1=$ first condition; $2=$ second condition, $3=$ third condition, 4 = fourth condition; $m=$ mediating effect.

c $\quad * \mathrm{p}<0.05 ; * * \mathrm{p}<0.01 ; * * * \mathrm{p}<0.001$

The second model was proposed to test the relations between destination personality and behavioral intentions. This model includes two causal relations: (1) from destination personality as exogenous variable to purchase intentions as endogenous variable; (2) from destination personality as exogenous variable to word-of-mouth intentions as endogenous variable. The goodness-of-fit statistics revealed a satisfactory model fit for this model as indicated in table (7). The SEM results supported the $5^{\text {th }}$ and $6^{\text {th }}$ hypotheses where destination personality has positive significant effects on both purchase intentions $(\beta=0.236$, $p$-value $<0.001)$ and word-of mouth intentions $(\beta=0.206, p$-value $=$ 0.002). The results of squared multiple correlations indicated that destination image is responsible for $5.6 \%$ of changes occurred in purchase intentions of tourists and $4.3 \%$ of changes occurred in word-of-mouth intentions.

\section{The mediating effects of destination personality toward behavioral intentions}

For testing the seventh hypothesis which claimed that destination personality has a mediating effect between destination image and behavioral intentions, there are generally three major frameworks: the causal steps approach, differences in coefficients, and product of coefficients (Wood, Goodman, Beckmann, \& Cook, 2008). ${ }^{67}$ Baron and Kenny's ${ }^{68}$ causal steps approach was used in this study as it has been adopted the most by studies in management ${ }^{67}$ as well as in hospitality and tourism ${ }^{69} 70$. Four conditions were recommended by Baron and Kenny ${ }^{68}$ : (1) the independent variable must be shown to affect the mediator in the absence of the dependent variable; (2) the independent variable must be shown to affect the dependent variable in the absence of the mediator; (3) the mediator must affect the dependent variable in the presence of the independent variable; and the independent variable must affect the dependent variable in the presence of the mediator; and (4) once the above conditions all hold in the predicted direction, the effect of the independent variable on the dependent variable must be less in the third condition than in the second condition.

The results of the first model satisfy only the $2^{\text {nd }}$ condition as the independent variable (destination images) showed to affect the dependent variable (behavioral intentions) in the absence of the mediator variable (destination personality). For satisfying the remaining conditions of Baron and Kenny ${ }^{68}$, the $3^{\text {rd }}$ and $4^{\text {th }}$ models were proposed. The $3^{\text {rd }}$ model was proposed to verify the first condition by testing the relation between independent variable (destination image) and mediator variable (destination personality) in the absence of dependent variables. The results in table (7) showed acceptable model with satisfactory fit statistics. The results in table (8) satisfied the first condition and showed a significant relation between destination image and destination personality. Destination personality has been positively influenced by both cognitive image $(\beta=0.294$, p-value $<0.001)$ and affective image $(\beta=0.448, p$-value $<0.001)$ at 0.001 confidence interval.

For satisfying the $3^{\text {rd }}$ and $4^{\text {th }}$ conditions, a fourth model was proposed to test the relations between destination image and behavioral intentions in the presence of destination personality, and also test the relations between destination personality and behavioral intentions in the presence of destination image. So, a five-construct model with eight causal relations or paths were designed: 1) from cognitive image as exogenous variable to purchase intentions as endogenous variable; 2) from cognitive image as exogenous variable to word-of-mouth intentions as endogenous variable; 3) from affective image as exogenous variable to purchase intentions as exogenous variable; 4) from affective image as exogenous variable to word-of-mouth intentions as exogenous variable; 5) from cognitive image as exogenous variable to destination personality as endogenous variable; 6) from affective destination image as exogenous variable to destination personality as exogenous variable; 7) from destination personality as exogenous 
variable to purchase intentions as endogenous variable; and 8) from destination personality as exogenous variable to word-of-mouth intentions as endogenous variable.

The results of descriptive fit statistics in table (7) ensured that the overall $4^{\text {th }}$ model fit is quite reasonably adequate for further analysis. The results of SEM analysis indicated in table (8) satisfied the $3^{\text {rd }}$ condition where cognitive image affects both purchase intentions $(\beta=0.263$, p-value $<0.001)$ and word-of-mouth intentions $(\beta=0.356, p$ value $<0.001)$ at 0.01 confidence interval. Affective image affects both purchase intentions $(\beta=-0.035$, $p$-value= $0.626)$ and word-of-mouth intentions $(\beta=0.065$, $p$-value $=0.358)$, but these influences are not significant. Also, the relation between destination personality and behavioral intentions is supported. Destination personality has significant effect on purchase intentions $(\beta=0.164$, p-value $=0.031)$ and insignificant effect on word-of-mouth intentions $(\beta=0.294$, $p$-value $=0.436)$. By comparing standard coefficient values in the $1^{\text {st }}$ and $4^{\text {th }}$ models, it is observed that the fourth condition is satisfied whereas the effects of the independent variables (cognitive image and affective image) on the dependent variables (purchase intentions and word-of-mouth intentions) are less in the $4^{\text {th }}$ model results than in the $1^{\text {st }}$ model results. Therefore, the $7^{\text {th }}$ hypothesis is supported whereas destination personality has a mediating effect on the relationship between destination image and behavioral intentions. So, the seventh hypothesis is supported.

In sum, based on the results of the four proposed structural models, it is concluded that both destination image and destination personality relates directly to behavior intentions. On the other hand, destination personality plays a mediating role between destination image and behavioral intentions. Therefore, the best suitable model, that describes the relation between the identified elements of destination brand and behavioral intentions, can be designed as indicated in figure 1 . It shows that both cognitive image $(\beta=0.294, p$-value $<0.001)$ and affective image $(\beta=0.448$, $p$-value $<0.001)$ have significant positive effects on destination personality which in turn has a significant positive effect on purchase intentions $(\beta=0.164, p$-value $=0.031)$ and insignificant positive effect on word-of-mouth intentions $(\beta=0.058$, $\mathrm{p}$-value $=0.436)$.

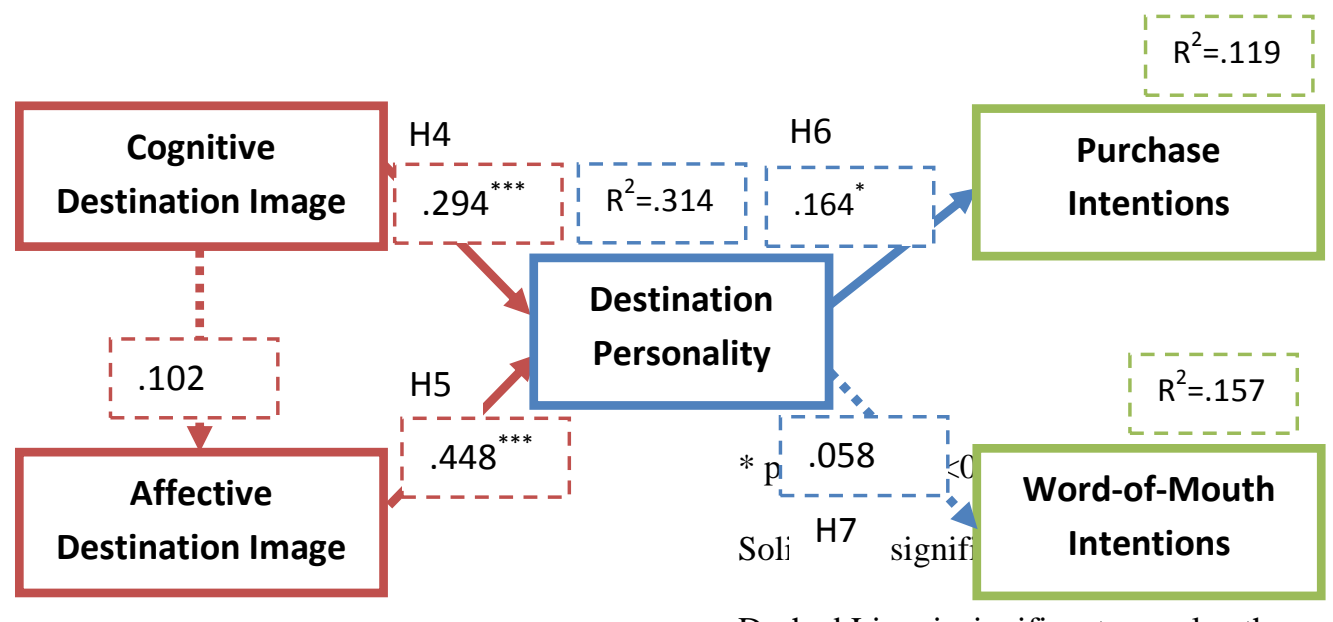

Dashed Line: insignificant causal path

Figure (2): Estimates of the Best Model

\section{CONCLUDING COMMENTS}

This study was conducted for empirically testing the causal relationships between destination brand and travel behavior to examine whether destination image has a direct or indirect effects on behavioral intentions. The structural analysis was conducted by using SEM analysis to ensure the hypothesized causal relations among identified constructs. Using Arabian tourism destinations as a setting, this study contributes to the debate on the destination brand-travel behavior relation. While previous research findings indicated that destination image had both direct and indirect effects on behavioral intentions ${ }^{810445152}$, a debate exists regarding the mediator between destination image and behavioral intentions. Different studies asserted many mediators between destination image and behavior intentions such as tourist satisfaction ${ }^{9}{ }^{46}$; satisfaction and quality ${ }^{48}{ }^{53}$; satisfaction, quality, and 
perceived value ${ }^{45}$; satisfaction and overall image ${ }^{55}$. A little studies examined the mediating role of destination personality between destination image ${ }^{1117}$.

In this study, the results of SEM concluded that the identified constructs of destination brand - destination image and destination brand, affect directly behavioral intentions of international tourists in Oman. Both cognitive image and destination personality have significant direct and positive effects on both purchase intentions and word-ofmouth of tourists. Although affective image has direct positive effects on behavioral intentions constructs, there is no evidence to support these effects. Otherwise, the results assured the mediating role of destination personality between constructs of destination image and constructs of behavioral intentions. Therefore, the most suitable structural model is that destination image indirectly affects behavior of tourists through the mediating variable of destination personality.

By close examination of the concluded structural model, the results showed that both destination image and affective image have significant positive effects on destination personality. These results are parallel with results from other studies $^{31756}$. While both cognitive and affective images are responsible for more than thirty percent of the variances occurred in destination personality, affective image has more positive influence on destination personality. Hosany et al. ${ }^{3}$ ensured similar results as brand personality is more related to the affective components of brand image. Furthermore, the SEM outputs revealed that destination personality has direct positive impact on both purchase intentions and word-of-mouth intentions of inbound tourists to Oman. These impacts are significant only in case of purchase intentions. In addition to direct positive impact of destination personality on behavioral intentions, it has a mediating effect on the relationship between destination image and behavioral intentions. Previous research findings indicated that destination image had both direct and indirect effect on behavioral intentions. ${ }^{9} 104445485152$ Furthermore, Ekinci and Hosany ${ }^{11}$ and $\mathrm{Xie}^{17}$ supported the assertion of mediating effect of destination personality on the relation between destination image and behavioral intentions.

Tourism related decision makers in Oman should take these results in their considerations especially with developing and designing marketing plans and brand positioning strategies. As the success of any vacation destination depends on the tourist's willingness and intention to visit the destination, any effort made to provide accurate information concerning the destination should be tailored to suit the needs and expectations of those tourists. Future studies should investigate the antecedents of travel behavior and test other mediators between destination brand and behavioral intentions of tourists.

\section{REFERENCES}

${ }^{1}$ Greaves, N., \& Skinner, H. (2010). The importance of destination image analysis to UK rural tourism. Marketing Intelligence and Planning, 28(4), 486-507.

${ }^{2}$ Pritchard, A., \& Morgan, N. (1998). Mood marketing: The new destination branding strategy - A case study of 'Wales' the brand. Journal of Vacation Marketing, 4(3), 215-229.

${ }^{3}$ Hosany, S., Ekinci, Y., \& Uysal, M. (2006). Destination image and destination personality: An application of branding theories to tourism places. Journal of Business Research, 59, 638-642.

${ }^{4}$ Tasci, A. D. A., \& Kozak, M. (2006). Destination brands vs destination images: Do we know what we mean? Journal of Vacation Marketing, 12(4), 299-317.

${ }^{5}$ Morgan, N., Pritchard, A., \& Piggott, R. (2002). New Zealand, 100\% Pure: The creation of a powerful niche destination brand. Journal of Brand Management, 9(4/5), 335-354.

${ }^{6}$ Henderson, J. C. (2007). Uniquely Singapore? A case study in destination branding. Journal of Vacation Marketing, 13(3), 261-274.

${ }^{7}$ Nicolaisen, J., \& Blichfeldt, B. S. (2012). Destination branding: mission impossible? Working paper no. 9. TRU Progress, Aalborg University, Denmark.

${ }^{8}$ Baloglu, S., \& McCleary, K. W. (1999). A model of destination image formation. Annals of Tourism Research, 26(4), 868-897. 
${ }^{9}$ Chi, C., \& Qu, H. (2008). Examining the structural relationships of destination image and destination loyalty: An integrated approach. Tourism Management, 29, 624-636.

${ }^{10}$ Phau, I., Shanka, T., \& Dhayan, N. (2010). Destination image and choice intention of university student travellers to Mauritius. International Journal of Contemporary Hospitality Management, 22(5), 758764

${ }^{11}$ Ekinci, Y., \& Hosany, S. (2006). Destination personality: an application of brand personality to tourism destinations. Journal of Travel Research, 45(2), 127-139.

${ }^{12}$ Murphy L., Moscardo G., \& Benckendorff, P. (2007). Using brand personality to differentiate regional tourism destinations. Journal of Travel Research, 46(5), 5-14.

13 Conejo, F. (2007). The tourism destination personality scale. Unpublished Thesis, Department of Marketing, University of Otago, New Zealand.

${ }^{14}$ Gilmore, F. (2002). A country-can it be repositioned Spain: The success story of country branding. Journal of Brand Management, 9(4/5), 218-284.

${ }^{15}$ Hall, J. (2004). Branding Britain. Journal of Vacation Marketing, 10(2), 171-185.

${ }^{16}$ Obaid, M. A. A. (2014). Cognitive image and affective image of Oman tourism destination: Examining their relationships to destination personality. Egyptian Journal of Tourism and Hospitality (April, 2014), 118-156.

17 Xie, K. L. (2011). Examining structural relationships among cognitive destination image, destination personality and behavioural intentions: The case of Beijing. Unpublished Thesis, School of Hotel and Tourism management, the Hong Kong Polytechnic University, China.

${ }^{18}$ Milman, A., \& Pizam, A. (1995). The role of awareness and familiarity with a destination: The Central Florida case. Journal of Travel Research. 33 (3), 21-27.

${ }^{19}$ Ritchie, B. J. R., \& Ritchie, R. J. B. (1998). The branding of tourism destination: Past achievements and future trends in destination marketing - Scope and limitations. Reports of $48^{\text {th }}$ Congress, AIEST, StGall, 89-116.

${ }^{20}$ Blain, C., Levy, S. E., \& Ritchie, J. R. (2005). Destination branding: Insights and practices from destination management organizations. Journal of Travel Research, 43, 328-38.

${ }^{21}$ World Tourism Organization and European Travel Commission (2009). Handbook on tourism destinations branding ( $1^{\text {st }}$ Ed.). Spain, Madrid: Author

${ }^{22}$ Saraniemi, S. (2011). From destination image building to identity-based branding. International Journal of Culture, Tourism and Hospitality Research, 5(3), 247-254.

${ }^{23}$ Beerli, A., \& Martin, J. D. (2004). Factors influencing destination image. Annals of Tourism Research, $31(3), 657-681$.

${ }^{24}$ Crompton, J. L. (1979). An assessment of the image of Mexico as a vacation destination and the influence of geographical location upon that image. Journal of Travel Research, 17(4), 18-24.

${ }^{25}$ Frias, D. M., Rodriguez, M. A., \& Castaneda, J. A. (2007). Internet vs travel agencies on pre-visit destination image formation: An information processing view. Tourism Management, 29(1), 163-179.

${ }^{26}$ Ward, L. M., \& Russell, J. A. (1981). Cognitive set and the perception of place. Environment and Behavior, $13,610-632$.

${ }^{27}$ Gartner, W. C. (1993). Image formation process. Journal of Travel Research and Tourism Marketing, 2(3), 197-212. 
${ }^{28}$ Fakeye, P., \& Crompton, J. (1991). Image difference between prospective, first-time and repeat visitors to the lower Rio Grande Valley. Journal of Travel Research 30(2), 10-16.

${ }^{29}$ Pike, S. (2004). Destination Marketing Organizations. UK: Elsevier publisher.

${ }^{30}$ Aaker, J. L. (1997). Dimensions of brand personality. Journal of Marketing Research, 34, 347-356.

${ }^{31}$ Baloglu, S., \& Mangaloglu, M. (2001). Tourism destination images of Turkey, Egypt, Greece, and Italy as perceived by US-based tour operators and travel agents. Tourism Management, 22, 1-9.

32 Tasci, A. D. A., \& Gartner, W. C. (2007). Destination image and its functional relationships. Journal of Travel Research, 45(4), 413-425.

${ }^{33}$ Hsu, C. H., Wolfe, K., \& Kang, S. K. (2004). Image assessment for a destination with limited comparative advantages. Tourism Management, 25, 121-126.

${ }^{34}$ Hankinson, G. (2004). The brand images of tourism destinations: A study of the saliency of organic images. Journal of Product and Brand Management, 33(1), 6-14.

${ }^{35}$ Vaidya, R., Gandhi, P., \& Aagja, J. (2009). Brand personality and perception measure of two cities: Surat and Ahmedabad. Journal of Brand Management, 6(1), 75-73.

${ }^{36}$ Konecnik, M., \& Go, F. (2008). Tourism destination brand identity: The case of Slovenia. Brand Management, 15(3), 177-189.

${ }^{37}$ Cai, L. (2002). Cooperative branding for rural destinations. Annals of Tourism Research, 29(3), 720-742.

${ }^{38}$ Pike, S. (2005). Tourism Destination Branding Complexity. Journal of Product and Brand Management, 14(4), 258-259.

${ }^{39}$ Pike, S., \& Ryan, C. (2004). Destination positioning analysis through a comparison of cognitive, affective and conative perceptions. Journal of Travel Research, 42(4), 333-342.

${ }^{40}$ Ajzen, I. (1991). The theory of planned behavior. Organizational Behavior and Human Decision Processes, $50,179-211$.

${ }^{41}$ Petrick, J., \& Bachman, S. (2002). An examination of the construct of perceived value for the prediction of golf travelers' intentions to revisit. Journal of Travel Research, 41(1), 38-45.

${ }^{42}$ Zeithamle, V. A., Berry, L. L., \& Parasuraman, A. (1996). The behavioral consequences of service quality. Journal of Marketing, 60(2), 31-46.

${ }^{43}$ Petrick, J. (2004). The roles of quality, value, and satisfaction in predicting cruise passengers' behavioral intentions. Journal of Travel Research, 42(4), 397-407.

${ }^{44}$ Alcaniz, E. B., Sanchez, I. S., \& Blas, S. S. (2009). The functional-psychological continuum in the cognitive image of a destination: A confirmatory analysis. Tourism Management, 30, 715-723.

${ }^{45}$ Castro, C. B., Armario, E. M., \& Ruiz, D. M. (2007). The influence of market heterogeneity on the relationship between a destination's image and tourists' future behavior. Tourism Management, 28, 175-187.

${ }^{46}$ Lee, T. H. (2009). A structural model to examine how destination image, attitude, and motivation affect the future behavior of tourists. Leisure Sciences, 31, 215-236.

${ }^{47}$ Baker, D., \& Crompton, J. (2000). Quality, satisfaction and behavioural intentions. Annals of Tourism Research, 27(3), 785-804.

${ }^{48}$ Chen, C. F., \& Tsai, D. C. (2007). How destination image and evaluative factors affect behavioral intentions? Tourism Management, 28, 1115-1122. 
${ }^{49}$ Kozak, M. (2001). Repeaters' behavior at two distinct destinations. Annals of Tourism Research, 28(3), 784-807.

${ }^{50}$ Grgona, J. (2003). Image of a tourist destination: A contribution to a scientific debate. Acta Turistica, 15(1), $38-60$.

${ }^{51}$ O'Leary, S., \& Deegan, J. (2005). Ireland's image as a tourism destination in France: Attribute importance and performance. Journal of Travel Research, 43, 247-256.

${ }^{52}$ Gras, M. K. (2008). Determining the relationship between destination brand image and its components with intention to visit. Unpublished Thesis, Cameron School of Business, University of North Carolina Wilmington, USA.

${ }^{53}$ Bigne, J., Sanchez, M., \& Sanchez, J. (2001). Tourism image, evaluation variables and after purchase behavior: inter-relationships. Tourism Management, 22(6), 607-616.

${ }^{54}$ Chi, C., \& Qu, H. (2008). Examining the structural relationships of destination image and destination loyalty: An integrated approach. Tourism Management, 29, 624-636.

${ }^{55}$ Prayag, G. (2009). Tourists' evaluations of destination image, satisfaction, and future behavioral intentions: The case of Mauritius. Journal of Travel and Tourism Marketing, 26(8), 836-853.

${ }^{56}$ Papadimitrious, D., Apostolopoulou, A., \& Kaplanidou, K. (2013). Destination personality, affective image, and behavioral intentions in domestic urban tourism. Journal of Travel Research (December 30). doi:10.1177/0047287513516389

${ }^{57}$ Chalip, L., Green, B. C., \& Hill, B. (2003). Effects of sport event media on destination image and intention to visit. Journal of Sport Management, 17, 214-234.

${ }^{58}$ Obenour, W., Lengfelder, J., \& Groves, D. (2005). The development of a destination through the image assessment of six geographic markets. Journal of Vacation Marketing, 11, 107-119.

${ }^{59}$ Aksu, A. A., Caber, M., \& Albayrak, T. (2009). Measurement of the destination evaluation supporting factors and their effects on behavioral intention of visitors: Antalya region of Turkey. Tourism Analysis, 14, 115-125.

${ }^{60}$ Byon, K. K., \& Zhang, J. J. (2010). Development of a scale measuring destination image. Marketing Intelligence and Planning, 28(4), 508-532.

${ }^{61}$ Anderson, D. R., \& Gerbing, D. W. (1988). Structural equation modeling in practice: A review and recommended two-step approach. Psychological Bulletin, 103, 411-423.

${ }^{62}$ Hair, J.F., Black, W., Babin, B., \& Anderson, R. E. (2010). Multivariate data analysis: A global perspective ( $7^{\text {th }}$ ed.). USA: Pearson Prentice Hall.

${ }^{63}$ Byrne, B. M. (2013). Structural Equation Modeling with AMOS: Basic Concepts, Applications, and Programming ( $2^{\text {nd }}$ ed.). UK: Routledge.

${ }^{64}$ Campbell, D., \& Fiske, D. (1959). Convergent and discriminant validation by the multitrait-multimethod matrix. Psychological Bulletin, 56 (2), 81-105.

${ }^{65}$ Fornell, C., \& Larcker, D. F. (1981). Evaluating structural equation models with unobservable variables and measurement error. Journal of Marketing Research, 18, 39-50.

${ }^{66}$ Bentler, P. M. (1983). Some contributions to efficient statistics in structural models: Specification and estimation of moment structure. Psychometrika, 48(1), 493-517.

${ }^{67}$ Wood, R. E., Goodman, J. S., Beckmann, N., \& Cook, A. (2008). Mediation testing in management research. Organizational Research Methods, 11(2), 270-295. 
${ }^{68}$ Baron, R. M., \& Kenny, D. A. (1986). The moderator-mediator variable distinction in social psychological research: Conceptual, strategic, and statistical considerations. Journal of Personality and Social Psychology, 51(6), 1173-1182.

${ }^{69}$ Back, K. (2005). The effects of image congruence on customers' brand loyalty in the upper middle-class hotel industry. Journal of Hospitality and Tourism Research, 29(4), 448-467.

${ }^{70}$ He, Y., \& Song, H. (2009). A mediation model of tourists'repurchase intentions for packaged tour services. Journal of Travel Research, 47 (3), 317-331.

\footnotetext{
العلامة التجارية للمقصد السياحي وسلوك السفر: دراسة تأثيرات الصورة الذهنية وشخصية المقصد السياحي 